Maurice A. de Gosson

Quantum Harmonic Analysis 


\section{Advances in Analysis and Geometry}

\section{Editor-in Chief}

Jie Xiao, Memorial University, Canada

\section{Editorial Board}

Der-Chen Chang, Georgetown University, USA

Goong Chen, Texas A\&M University, USA

Andrea Colesanti, University of Florence, Italy

Robert McCann, University of Toronto, Canada

De-Qi Zhang, National University of Singapore, Singapore

Kehe Zhu, University at Albany, USA

\section{Volume 4}


Maurice A. de Gosson

Quantum

Harmonic Analysis

An Introduction

DE GRUYTER 
Mathematics Subject Classification 2010

Primary: 32A50, 51A50, 81Qxx; Secondary: 35Q40, 35S05, 47G30

\section{Author}

Prof. Dr. Maurice A. de Gosson

University of Vienna

Faculty of Mathematics

Oskar-Morgenstern-Platz 1

1090 Vienna

Austria

maurice.de.gosson@univie.ac.at

ISBN 978-3-11-072261-1

e-ISBN (PDF) 978-3-11-072277-2

e-ISBN (EPUB) 978-3-11-072290-1

ISSN 2511-0438

Library of Congress Control Number: 2021934872

Bibliographic information published by the Deutsche Nationalbibliothek The Deutsche Nationalbibliothek lists this publication in the Deutsche Nationalbibliografie; detailed bibliographic data are available on the Internet at http://dnb.dnb.de.

(C) 2021 Walter de Gruyter GmbH, Berlin/Boston

Typesetting: VTeX UAB, Lithuania

Printing and binding: $\mathrm{CPI}$ books $\mathrm{GmbH}$, Leck

www.degruyter.com 
To Charlyne and to our children

Serge, Corinne, Samantha, and Sven

With all my love 
